\title{
Seed Morphology of Some Selected Species of Fabaceae, Polygonaceae, Primulaceae, Violaceae, Rosaceae and Phyllanthaceae
}

\section{Seyran PALABAŞ UZUN ${ }^{1 *}$, Alper UZUN ${ }^{1}$, Eda ALICI $^{2}$}

\begin{abstract}
Determination of some seed characteristics provides important distinctive taxonomic data for species identification. In this study, seed characteristics such as measurements, weights and surface morphology of some unstudied taxa belonging to Fabaceae, Polygonaceae, Primulaceae, Violaceae, Rosaceae and Phyllanthaceae families native in Turkey, were investigated. Length and width of the seeds were measured with digital calliper using stereo-microscope. Seed weights were measured with Dikomsan precision scale. In addition to stereo microscope data, the surface ornamentation of the seeds was identified using scanning electron microscope. Accordingly, the smallest seeds were determined in Anagallis foemina $(0.74 \mathrm{~mm}$ long and $1.11 \mathrm{~mm}$ wide) from Primulaceae family, while the largest seeds were determined in Rosa boissieri (4.95 mm long and $2.99 \mathrm{~mm}$ wide) from Rosaceae family. The heaviest seeds were measured in Rosa boissieri ( $0.0095 \mathrm{~g})$ from the Rosaceae family and the slightest seeds in Anagallis foemina (0.0002 g) from the Primulaceae family. Mainly six types of the ornamentation were observed in SEM study of the species. The most common one was the reticulate ornamentation.
\end{abstract}

Keywords: Stereomicroscope measurements, scanning electron microscope (SEM), seed morphology, seed surface ornamentation

\section{Fabaceae, Polygonaceae, Primulaceae, Violaceae, Rosaceae ve Phyllanthaceae Familyalarına Ait Bazı Taksonların Tohum Morfolojileri}

ÖZET: Bazı tohum özelliklerinin belirlenmesi, türlerin tanımlanmasında önemli ayırt edici taksonomik veriler sağlar. Bu çalışma ile Türkiye'de yayılış gösteren Fabaceae, Polygonaceae, Primulaceae, Violaceae, Rosaceae ve Phyllanthaceae familyalarına ilişkin tohum özellikleri çalışılmamış bazı taksonların, en-boy ölçümleri, ağırlıkları ve yüzey morfolojileri çalışılmıştır. Bu çalışmada mikroskop ve milimetrik kumpas ile tohumların en-boy ölçümleri gerçekleştirilmiştir. Dikomsan marka hassas terazi ile tohumların ağırlıkları tartılmıştır. Stereo mikroskop verilerine ek olarak, taramalı elektron mikroskobu ile tohumların yüzey ornamentasyonu belirlenmiştir. Buna göre, en küçük tohumlar Primulaceae familyasından Anagallis foemina' da $(0,74 \mathrm{~mm}$ genişliğinde ve 1,11 mm uzunluğundadır), en büyük tohumlar ise Rosaceae familyasından Rosa boissieri' de tespit edilmiştir (2,99 mm genişliğinde ve 4,95 mm uzunluğundadır). En ağır tohumlar Rosaceae familyasından Rosa boissieri'de (0.0095 g) ve en hafif tohumlar Primulaceae familyasından Anagallis foemeina'da (0.0002 g) ölçülmüştür.

Anahtar Kelimeler: Stereo mikroskop ölçümleri, taramalı elektron mikroskop (SEM), tohum morfolojisi, tohum yüzeyi ornemantasyonu

\footnotetext{
${ }_{1}^{1}$ Seyran PALABAŞ UZUN (Orcid ID: 0000-0001-7090-4804), Alper UZUN (Orcid ID: 0000-0002-2577-7460), Kahramanmaraş Sütçü İmam Üniversitesi, Orman Fakültesi, Orman Mühendisliği Bölümü, Kahramanmaraş, Türkiye ${ }^{2}$ Eda ALICI (Orcid ID: 0000-0002-4324-7404), Kahramanmaraş Sütçü İmam Üniversitesi, Fen Bilimleri Enstitüsü, Orman Mühendisliği ABD, Kahramanmaraş, Türkiye

*Sorumlu Yazar/Corresponding Author: Seyran PALABAŞ UZUN, e-mail: seyran@ksu.edu.tr

Bu çalışma Eda ALICI'nın Yüksek Lisans tezinden üretilmiştir.

Makale 03-05 Ekim 2019 tarihlerinde Kahramanmaraş’ta düzenlenen “III. International Mediterranean Forest and Environment Symposium” da sözlü olarak sunulmuştur.
} 


\section{INTRODUCTION}

Seed, which will form the next generations in seed plants (Spermatophyta), consists of mainly three parts; embryo, seed coat (testa) and endosperm. The seed coat is the direct interface between the embryo and the external environment, it protects against pathogens and adverse conditions, contributes to the embryo nutrition and growth. The seeds of different species have evolved to a great extent in their structural and anatomical features and sizes. For example, the weight of an orchid seed may be 0.003 $\mathrm{mg}$, while a coconut (Lodoicea maldvica) can be over $20 \mathrm{~kg}$ (Sliwinska and Bewley, 2014; Salmeri et al., 2015).

Seed is one of the most frequently used sources of information in defining plant species. Seed ornamentations provide information for the analysis of taxonomic relationships in many plant families, genera, and also critical taxa, because they are affected slightly by the environmental conditions as they develop and mature in fruits. Scanning electron microscope has been used to identify important seed coat models that can help identify species characteristics better (Barthlott, 1981; Heywood, 1971). During the last decades, using the scanning electron microscopes has greatly increased our knowledge about macro and micromorphological characteristics of seeds (Vural et al., 2008; Morozowska et al., 2011; Kantachot and Chantaranothai, 2011; Sliwinska and Bewley, 2014; Salmeri et al., 2015; Ninkaew et al., 2017).

Turkey is an important country with a richness of plant species (167 families, 1320 genera and 9996 plant species) in terms of seed sources (Güner et al., 2012). But still the seed surface morphology of some taxa in Turkish flora has not been studied.

The main aim of this study is to give information about the seed characteristics of unstudied taxa belonging to Fabaceae, Polygonaceae, Primulaceae, Violaceae, Rosaceae and Phyllanthaceae families. Determining the seed characteristics of the taxa examined in these families will provide useful data in advanced systematic evaluations. In this study, seed macro and micro morphological characteristics of the taxa were studied by both stereo and scanning electron microscope (SEM).

\section{MATERIAL AND METHOD}

The seeds for each taxa were collected from their wild growing conditions during the years 20012011, out of which were collectively represented in Table 1(Palabaş Uzun and Anşin, 2006; Uzun and Terzioğlu, 2008; Palabaş Uzun and Terzioğlu, 2019).

For morphological examination, the polar (length) and equatorial (width) measurements of the seeds were obtained from digital calliper using stereo-microscope. The weights of the seeds were weighed out with Dikomsan precision scales and the average weights were calculated by dividing the number of seeds. For each species, measurements were made at 30 seeds sample.

Leica APO 8 stereomicroscope was used to determine the morphological characteristics and colours of the seeds. At the same time, micro photographs of seed samples were obtained with digital photographic system.

Scanning Electron Microscope (SEM) photographs of the seeds were taken in Microscopic Analysis Laboratory, Kahramanmaraş Sütçü İmam University, University-Industry-Public Cooperation Centre (ÜSKIMM). Seed samples were mounted on metal stubs using double-sided sticky tape and gold coated so that they could become conductive and display on the electron microscope screen. Micro photographs were taken with EVO LS10 scanning electron microscope (SEM). For each taxa examined, micro photographs were obtained at different magnifications. 
Terminology for descriptions of morphological characteristics of the seeds followed Bojnanský and Fargašová (2007).

Table 1. List of species analysed in the study

\begin{tabular}{|c|c|c|}
\hline Taxa & Voucher locations & Collection Number \\
\hline $\begin{array}{l}\text { Astragalus galegiformis L. } \\
\text { (Fabaceae) }\end{array}$ & A9 Artvin: city centre, roadside, $204 \mathrm{~m}, 06.06 .2011$ & ${ }^{1}$ KASOF: 1324 \\
\hline $\begin{array}{l}\text { Onobrychis oxydontha var. armena (Boiss. \& } \\
\text { Huet) Aktoklu (Fabaceae) }\end{array}$ & $\begin{array}{l}\text { A7 Trabzon: Maçka, Çeşmeler district, shrubby place, } \\
800 \text { m, 01.06.2008 }\end{array}$ & ${ }^{2}$ KATO: 17962 \\
\hline $\begin{array}{l}\text { Polygonum persicaria } \mathrm{L} . \\
\text { (Polygonaceae) }\end{array}$ & $\begin{array}{l}\text { A7: Trabzon, Şalpazarı, Sütpınarı village, riparian } \\
\text { area, } 1080 \mathrm{~m}, 01.09 .2005\end{array}$ & KATO: 16359 \\
\hline $\begin{array}{l}\text { Primula megaseifolia } \text { Boiss. \& Balansa } \\
\text { (Primulaceae) }\end{array}$ & $\begin{array}{l}\text { A7: Trabzon, Şalpazarı, Kireçhane, Fagus orientalis } \\
\text { forest, } 1584 \mathrm{~m}, 18.05 .2005\end{array}$ & KATO: 16097 \\
\hline $\begin{array}{l}\text { Anagallis foemina Mill. } \\
\text { (Primulaceae) }\end{array}$ & $\begin{array}{l}\text { A7: Trabzon, Şalpazarı, Sütpınarı village, roadside, } \\
1021 \mathrm{~m}, 11.07 .2005\end{array}$ & KATO: 16800 \\
\hline $\begin{array}{l}\text { Viola sieheana W.Becker } \\
\text { (Violaceae) }\end{array}$ & $\begin{array}{l}\text { A7: Trabzon, Şalpazarı, Şıłkıran, forest edge , } 1200 \\
\text { m, 27.04.2005 }\end{array}$ & KATO: 16228 \\
\hline $\begin{array}{l}\text { Rosa boissieri Crep. } \\
\text { (Rosaceae) }\end{array}$ & $\begin{array}{l}\text { A7: Trabzon, Altındere V., Haliya Y., alpine } \\
\text { vegetation, } 1900 \mathrm{~m}, 07.09 .2001\end{array}$ & KATO: 15405 \\
\hline $\begin{array}{l}\text { Andrachne telephioides } \mathrm{L} . \\
\text { (Phyllanthaceae) }\end{array}$ & $\begin{array}{l}\text { A7 Trabzon: Maçka, Çeşmeler district, stony hill, } 437 \\
\mathrm{~m}, 07.07 .2008\end{array}$ & KATO: 17985 \\
\hline
\end{tabular}

${ }^{1}$ KASOF: Herbarium of Faculty of Forestry, Kahramanmaraş Sütçü İmam University

${ }^{2}$ KATO: Herbarium of Faculty of Forestry, Karadeniz Technical University

\section{RESULTS AND DISCUSSION}

Macro and micro morphological data revealed that there were wide variations among taxa (Table 2). Data obtained from the study of stereomicroscope and SEM investigation are presented comparatively in Table 2. Colour, shape and size features of the seeds were macro morphologically examined. Astragalus galegiformis and Onobrychis oxydontha var. armena, both of species belong to Fabaceae, exhibited the same shape as reniform. The seeds of Anagallis foemina were polyquetrous while Primula megaseifolia seeds were circular although both are belong to Primulaceae family. The other taxa were elliptic-rhombic, plano-convex, obovoid and sectoroid shaped. When the seed colours of the studied taxa are compared, the three taxa are Brown (Astragalus galegiformis, Anagallis foemina, and Rosa boissieri), three taxa Dark Brown (Onobrychis oxydontha var. armena, Primula megaseifolia and Andrachne telephioides), one taxon is Black (Polygonum persicaria) and the last one is Strawcoloured (Viola sieheana).

Seed surfaces of the taxa were micro morphologically examined and surface ornamentations of them determined (Figures 4 and 5). Astragalus galegiformis (reticulate) and Onobrychis oxyodontha var. armena (reticulate-foveolate), belonging to same family (Fabaceae) have reticulate-type ornamentation. Other surface ornamentations according to the species were determined as follows: Polygonum persicaria (undulate); Primula megaseifolia (reticulate-verrucose); Anagallis foemina (hyaline papillate); Viola sieheana (tangentially elongated-areolate); Rosa boissieri (slightly reticulatescalariform) and Andrachne telephioides (rugose-foveolate). Micro morphological analysis, which conducted via scanning electron microscope, reveals that many structures or characteristics are differ from one another despite of look the same or similar in plants (Yiğit, 2016). 
Table 2. Comparison of seed characteristics

\begin{tabular}{lcccccc}
\hline Taxa & Seed shape & Ornamentation & Colour & $\begin{array}{c}\text { Seed length } \\
(\mathbf{m m})\end{array}$ & $\begin{array}{c}\text { Seed width } \\
(\mathbf{m m})\end{array}$ & $\begin{array}{c}\text { Weight } \\
(\mathbf{g})\end{array}$ \\
& & & & min-max & min-max & \\
\hline Astragalus galegiformis & reniform & reticulate & Brown & $1.05-2.90$ & $2.04-2.64$ & 0.0028 \\
\hline $\begin{array}{l}\text { Onobrychis oxydontha } \text { var. } \\
\text { armena }\end{array}$ & reniform & reticulate-foveolate & Dark Brown & $1.68-2.24$ & $2.51-2.92$ & 0.0055 \\
\hline Polygonum persicaria & elliptic-rhombic & undulate & Black & $2.52-2.79$ & $1.72-1.89$ & 0.0014 \\
\hline Primula megaseifolia & circular & reticulate-verrucose & Dark Brown & $0.87-1.46$ & $0.63-1.82$ & 0.0005 \\
\hline Anagallis foemina & polyquetrous & hyaline-papillate & Brown & $0.74-0.86$ & $1.11-1.45$ & 0.0002 \\
\hline Viola sieheana & obovoid & elongated-areolate & Straw-coloured & $2.24-2.42$ & $1.46-1.55$ & 0.0021 \\
\hline Rosa boissieri & plano-convex & $\begin{array}{c}\text { slightly reticulate- } \\
\text { scalariform }\end{array}$ & Brown & $2.23-4.95$ & $1.95-2.99$ & 0.0095 \\
\hline Andrachne telephioides & sectoroid & rugose-foveolate & Dark Brown & $1.09-1.20$ & $1.62-1.68$ & 0.0008 \\
\hline
\end{tabular}

Most of the species have small seeds with the following length and width seen in figures 1 and 2 .

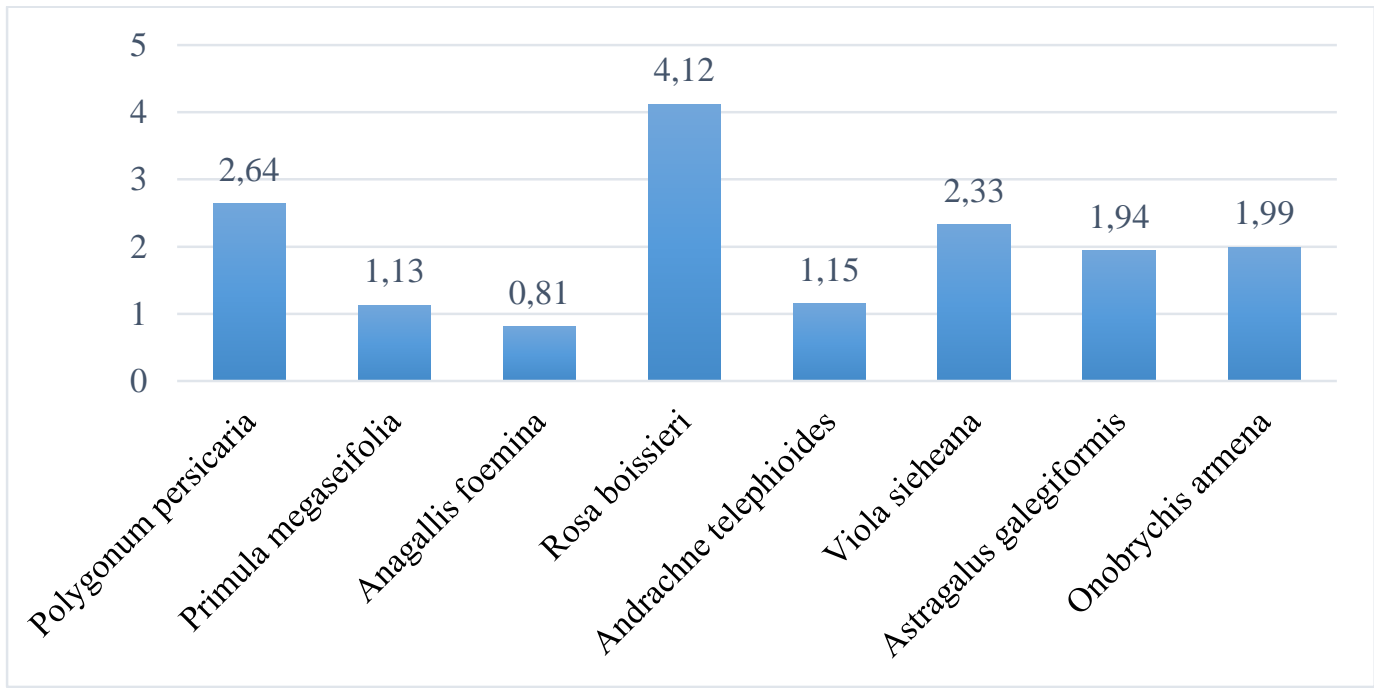

Figure 1. Average seed length $(\mathrm{mm})$ of the taxa

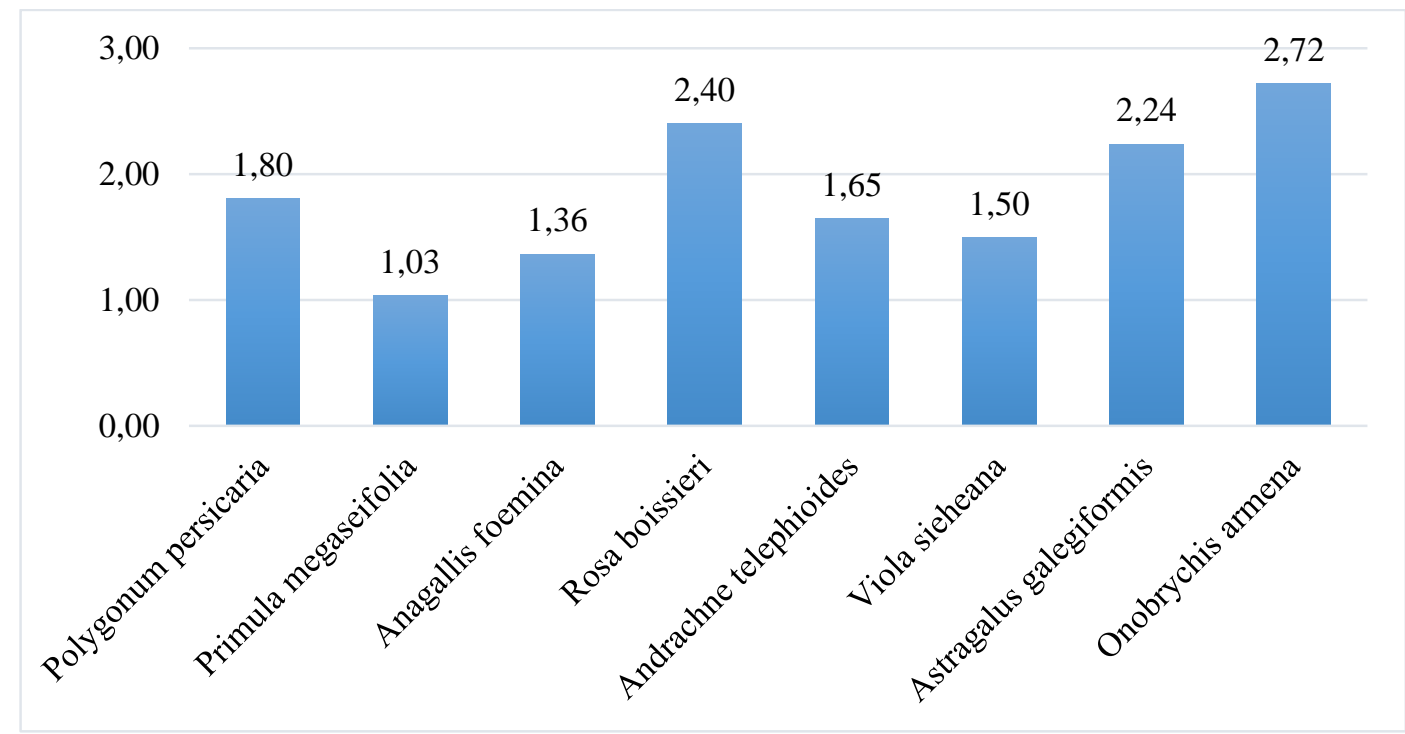

Figure 2. Average seed width (mm) of the taxa 


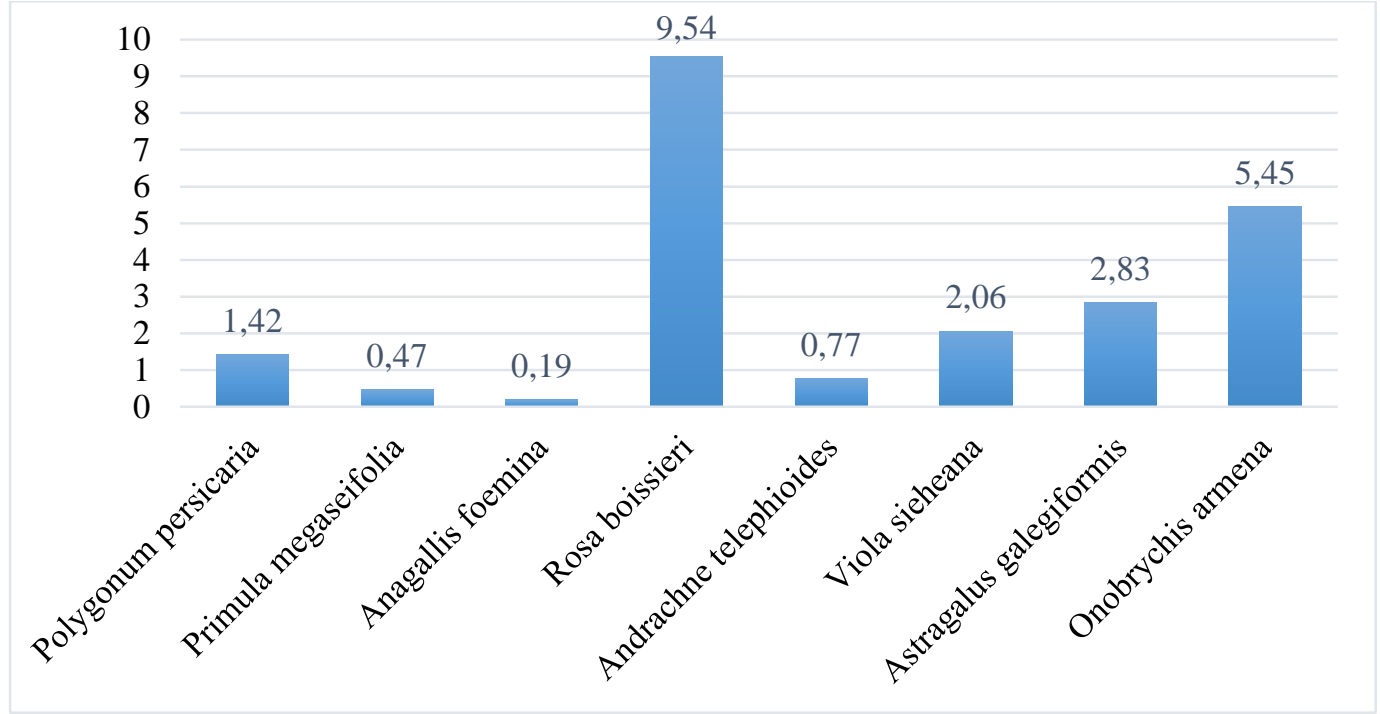

Figure 3. Thousand-seed weight (g) of taxa

In recent years, in addition to molecular and phylogenetic studies to determine the relationship of taxa the addition of morphological information plays a supporting role for understanding the phylogenetic relationships. Seed morphological structures generally show variations between taxa and these variations help to distinguish taxonomic levels (Morozowska et al. 2011; Karaismailoğlu et al. 2018)

In present study Astragalus galegiformis has reticulate surface ornamentation and the seed are reniform shaped. As a result of measurements, seed sizes were measured 1.05-2.90 $\mathrm{mm}$ in length and 2.04-2.64 mm in width. Shemetova et al. (2018) examined the seed morphology of 56 Astragalus taxa from North Asia and the seed shape of most of the examined taxa in the study was determined as reniform-globose. The surface ornamentation of the seeds was classified under two main types; as reticulate pattern and indistinctive reticulate pattern. Also Vural et al. (2008) examined the seed micromorphology of 48 species of Astragalus L., sections Onobrychoidei DC., Uliginosi Gray and Ornithopodium Bunge in Turkey that they identified two basic types of seed ornamentation: rugulate and rugulate-reticulate. When the studies are examined, it can be said that surface ornamentation is predominantly reticulate in Astragalus taxa, however, there are also some other ornamentation types such as regulate, faveolate and pectinate.

Özkan et al. (2015) investigated the seed morphology of four Onobrychis taxa from Turkey. They identified the seed shape is reniform, seed surface ornamentation is irregular reticulate and seed colour is light brown to yellow for Onobrychis tournefortii. They measured the seed sizes of Onobrychis tournefortii 4.0-4.1 mm in length and 2.0-2.1 mm in width. In our study, the seed shape of the Onobrychis oxydontha var. armena was determined as reniform, the seed surface ornamentation was determined as reticulate-foveolate and the seed colour as dark brown. The seed size was measured 1.682.24 in length and 2.51-2.92 in width. When we compared both taxa, it is seen that the seeds have different colours and size but the seed shapes and surface ornamentations are similar.

Kantachot and Chantaranothai (2011) have determined the seed morphology of 20 taxa belonging to Polygonum genus and identified the main surface patterns of ornamentation as smooth-undulate, a star-like form and reticulate-papillae. As compatible with the previous study seed surface ornamentation of Polygonum persicaria was determined as undulate. Mosaferi and Keshavarzi (2011) also examined 
morphological characters of Polygonaceae tribes of Iran and they stated that the achene morphology of members of the Polygonaceae tribes have taxonomic importance for delimitation of tribes and genera.
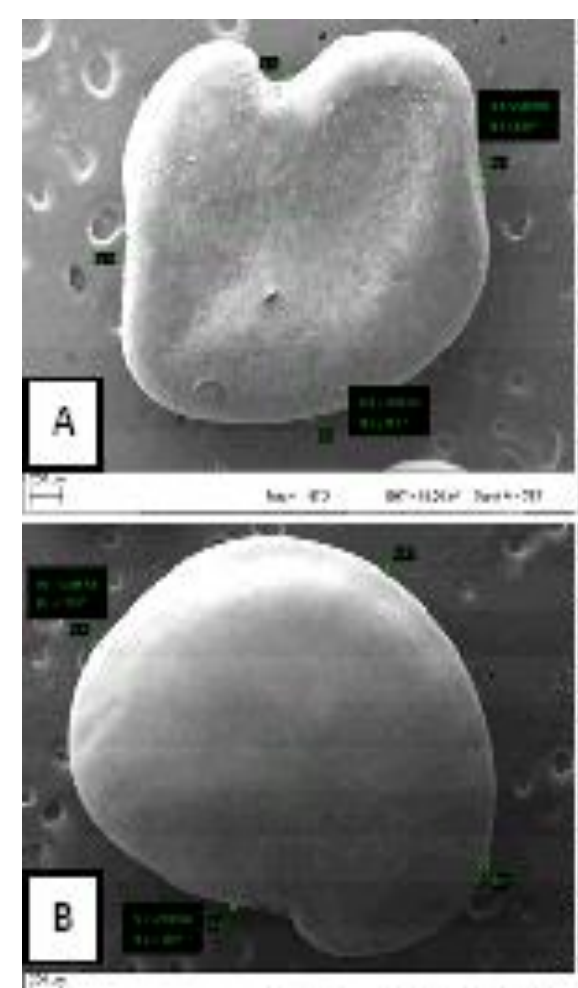

$4=\infty$

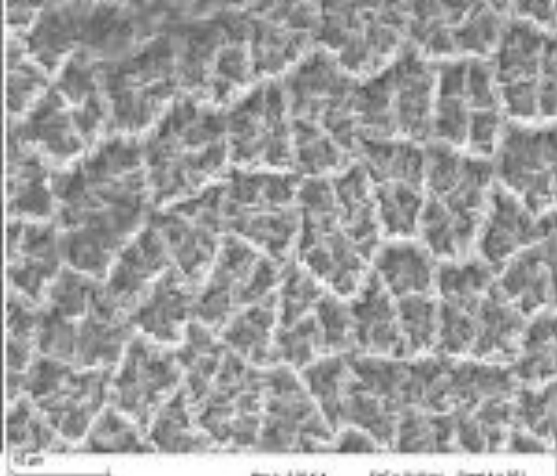

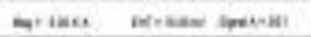

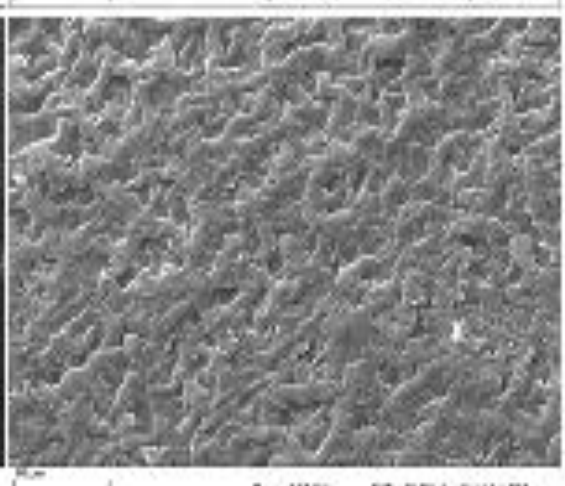

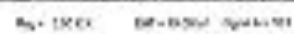

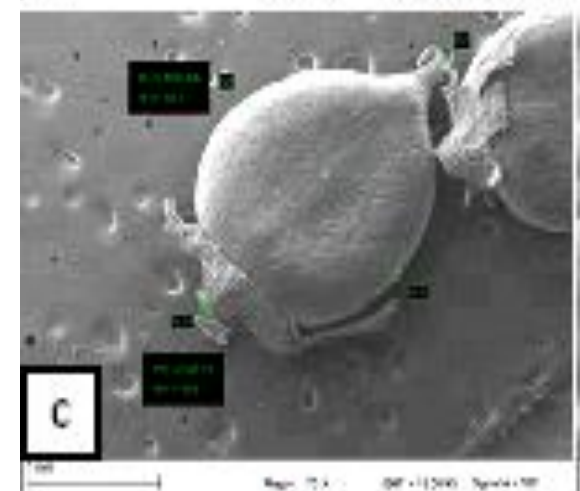

$\omega \rightarrow$

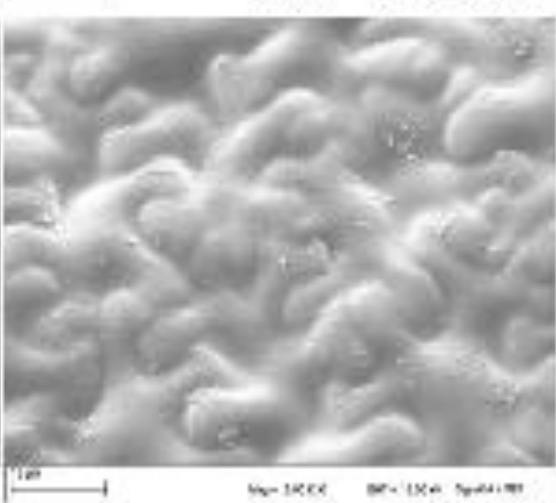

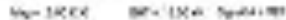

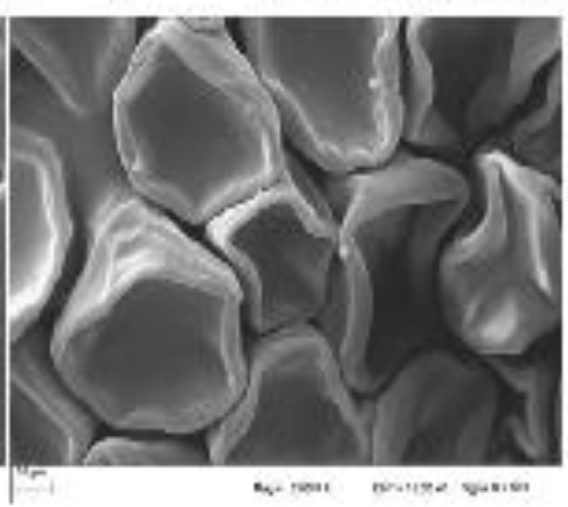

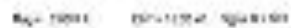
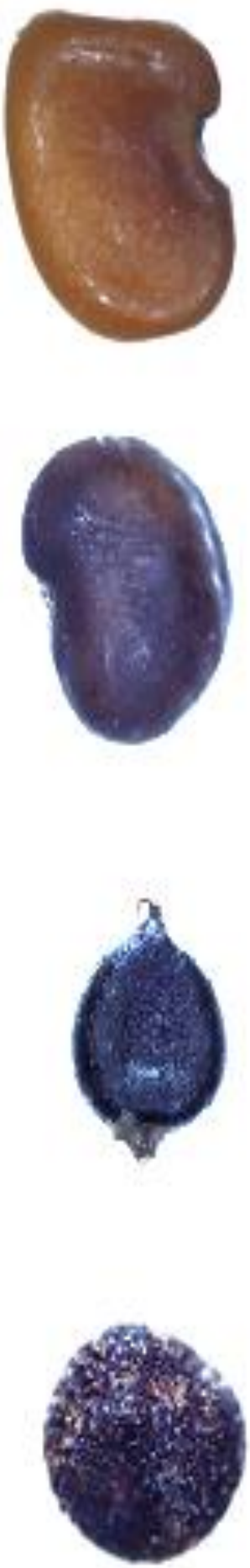

夏

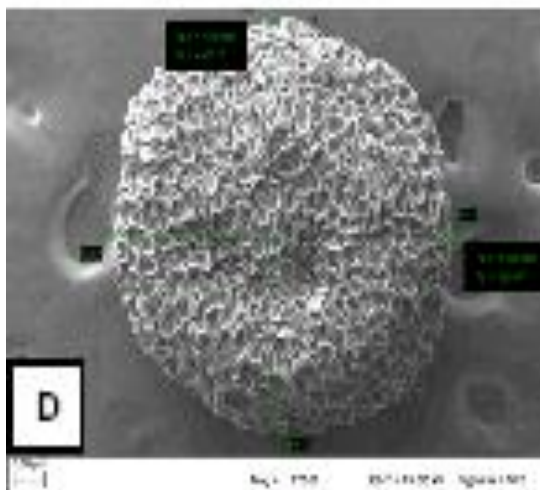

$m+m$

ninke verist

Figure 4. Astragalus galegiformis (A), Onobrychis oxydontha var. armena (B), Polygonum persicaria (C), Primula megaseifolia (D), (First column: Seed polar lengths and equatorial width; Second column: Seed ornamentation; and Third column: Stereomicroscope image and seed colour) 


\begin{tabular}{lr}
\hline Seyran PALABAŞ UZUN et al. & $10(3): 2028-2036,2020$ \\
\hline Seed Morphology of Some Selected Species of Fabaceae, Polygonaceae, Primulaceae, Violaceae, Rosaceae and Phyllanthaceae \\
\hline
\end{tabular}
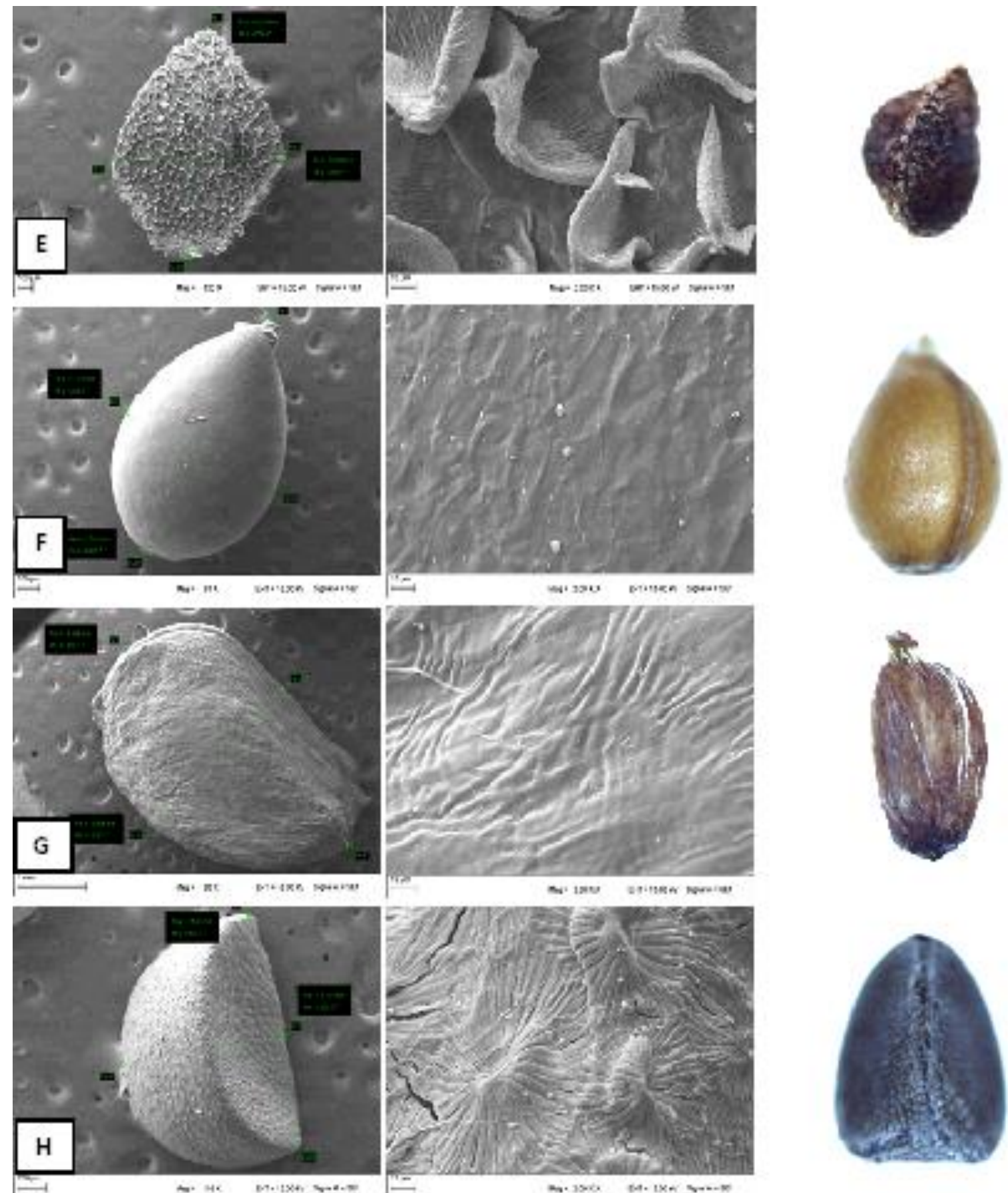

Figure 5. Anagallis foemina (E), Viola sieheana (F), Rosa boissieri (G), Andrachne telephioides (H). (First column: Seed polar lengths and equatorial width; Second column: Seed ornamentation; and Third column: Stereomicroscope image and seed colour)

Jagodzinski et al. (2016) investigated the achene morphology of most common Rosa taxa in Europe and stated that exocarp ornamentation is important in delimitation of Rosa taxa. They identified four types of ornamentation: scalariform, reticulate, reticulate-scalariform and very rarely smooth. In our study Rosa boissieri has slightly reticulate-scalariform ornamentation and seed sizes were measured 2.23-4.95 mm in length and 1.95-2.99 mm in width. Also Jagodzinski et al. (2016) stated that the length of the achenes have the highest taxonomic importance among the quantative features for Rosa taxa. 
Morozowska et al. (2011) investigated seed size and shape, seed coat surface pattern, seed coat thickness, and endosperm structure of Primula elatior and Anagallis arvensis in their study. They identified the seed shape is sectoroid in Anagallis while polyquetrous in Primula. In our study, we determined the seed shape of Anagallis foemina polyquetrous while circular in Primula megaseifolia. They also determined the seed surface ornamentation as tuberculate in Anagallis and Primula whereas we determined hyaline papillate in Anagallis foemina and reticulate-verrucose in Primula megaseifolia. Although the seeds in both studies are not exactly the same as surface ornamentation, they show similarity to each other.

\section{CONCLUSIONS}

There are a wide variety of seed shapes, colours, sizes and surface patterns. While some of these provide useful information in systematic evaluations such as surface ornamentation, others (seed sizes, weight) are affected by variables such as habitat condition, number of seeds in the plant and are not distinctive. Seed size is often adversely affected by the seed number. Like the seed sizes, the number of seeds produced by plants year after year may also differ. But the seed surface morphology seems to be a useful diagnostic character set at the interspecific level, especially for supporting the distinctive feature between similar species. In this study, seed surface morphology of eight taxa belonging to Fabaceae, Polygonaceae, Primulaceae, Violaceae, Rosaceae and Phyllanthaceae families were examined. Turkey has a great variety in terms of plant richness and such studies should be continued, based on a broader sampling of taxa, especially for taxonomically problematic ones. Finally, for this type of studies, mature stage of seeds should be taken into account. Because immature seeds can be cause incorrect measurements and evaluations.

\section{ACKNOWLEDGEMENTS}

Preliminary results of this study were presented in III. International Mediterranean Forest and Environment Symposium (IMFES2019) and published in proceedings. We thank the staff of Central Laboratory (ÜSKIM) for the works of Scanning Electron Microscope (SEM)

\section{REFERENCES}

Barthlott, W, 1981. Epidermal and seed surface characters of plants: systematic applicability and some evolutionary aspect, Nord J Bot 1: 345-355.

Bojnanský V, Fargašová A, 2007. Taxonomy and Morphology of Seeds. In Atlas of seeds and fruits of Central and East-European flora, Springer, pp. 1-954, Netherlands.

Davis, P.H., 1965-85. Flora of Turkey and the East Aegean Islands, I-IX., University Press, Edinburgh. Güner, A, Aslan, S, Ekim, T, Babaç, MT (edlr), 2012. "Türkiye Bitkileri Listesi (Damarlı Bitkiler)". Nezahat Gökyiğit Botanik Bahçesi ve Flora Araştırmaları Derneği Yayını. İstanbul, Türkiye.

Heywood, VH, 1971. Scanning Electron Microscopy. Systematic and Evolutionary Applications. London, UK: Academic Press.

Jagodziński, AM, Maciejewska-Rutkowska, I, Wrońska-Pilarek, D, Bocianowski, J, 2016. Taxonomic significance of achene morphology of selected Rosa taxa (Rosaceae) occurring in Poland, Acta Societatis Botanicorum Poloniae, 85 (2):3493

Kantachot, C, Chantaranothai, P, 2011. Achene Morphology of Polygonum s.1. (Polygonaceae) in Thailand, Tropical Natural History 11(1): 21-28. 
Karaismailoğlu MC, Ş1k L, Çiftçi A, Erol O, 2018. Seed structure of some taxa of the genus Crocus L. (Iridaceae) series Crocus. Turkish Journal of Botany, 42: 722-731.

Lundgren JG, 2009. Seed nutrition and defence. In: Lundgren JG, (ed.) Relationships of Natural Enemies and Non-prey Foods, Progress in Biological Control 7, Springer (Science + Business Media B.V.), pp. 183-209, New York, United States of America.

Morozowska M, Czarna A, Kujawa M, Jagodzinski MA, 2011. Seed morphology and endosperm structure of selected species of Primulaceae, Myrsinaceae, and Theophrastaceae and their systematic importance. Plant Systematics and Evolution, 291: 159-172.

Mosaferi, S, Keshavarzi, M, 2011. Micro-morphological study of Polygonaceae tribes in Iran, Phytologia Balcanica 17 (1): 89 -100.

Ninkaew S, Pornpongrungrueng P, Balslev H, Chantaranothai P, 2017. Seed morphology of nineteen Crotalaria L. (Fabaceae) species in Thailand. Thai Forest Bulletin (Botany), 45(1): 47-57.

Özkan M, Aktoklu E, Özdemir C, 2015. Seed Morphology in Onobrychis Miller Section Hymenobrychis DC. from Turkey, Planta Daninha, Viçosa. MG, 33(4): 699-705.

Palabaş Uzun S, Anşin R, 2006. Subalpine and Alpine Flora of Alt`ndere Valley (Maçka, Trabzon). Turkish Journal of Botany, 30: 381-398.

Palabaş Uzun S, Terzioğlu S, 2019. Sisdağı (Şalpazarı/Trabzon) ve Yöresinin Florası. Düzce Üniversitesi Bilim ve Teknoloji Dergisi, 7: 1523-1573.

Shemetova, T, Erst, A, Wang, W, Xıang, K, Vural, C, Aytaç, Z, 2018. Seed morphology of the genus Astragalus L. from North Asia, Turk J Bot 42: 710-721.

Sliwinska E, Bewley DJ, 2014. Overview of Seed Development, Anatomy and Morphology, Seeds. In: Gallagher RS, (ed.) The Ecology of Regeneration in Plant Communities, CAB International, 3rd Edition, p. 320.

Uzun A, Terzioğlu S, 2008. Vascular Flora of Forest Vegetation in Altındere Valley (Maçka-Trabzon). Turkish Journal of Botany, 30 (5): 381-398

Vural C, Ekici M, Akan H, Aytaç Z, 2008. Seed morphology and its systematic implications for genus Astragalus L. sections Onobrychoidei DC., Uliginosi Gray and Ornithopodium Bunge (Fabaceae). Plant Systematics and Evolution, 274: 255-263.

Yiğit N, 2016. Micromorphological Studies on Plants and Their Importance, In; Efe R, Matchavariani L, Yaldır A, Levai L, (eds.) Developments in Science and Engineering, ISBN 978954-07-4137-6, Sofia. 